УДК 37 .09: 61(091)

DOI: https://doi.org/10.35619/iiu.v0i9.147

Петренко Інна,

здобувач кафедри теорії і методики виховання

Рівненського державного гуманітарного університету,

м. Рівне, Україна

ORCID: 0000-0003-2320-6100

e-mail: inna.petrenko@rshu.edu.ua

\title{
ВНЕСОК ЛІКАРЯ-ГІГІЄНІСТА Ф. Ф. ЕРІСМАНА (1842-1915) В ОРГАНІЗАЦІЮ ОСВІТНЬОГО ПРОСТОРУ КЛАСНОЇ КІМНАТИ
}

Анотація. У статті здійснено аналіз внеску лікаря-гігієніста і педагога, засновника вітчизняної гігієнічної науки і наукової шкільної гігієни в Росії швейцарця за походженням Федора Федоровича Ерісмана (1842-1915) в організацію освітнього простору класної кімнати.

3'ясовано, що важливу роль у формуванні концептуальних ідей Ф. Ф. Ерісмана відіграла багатогранна діяльність вченого, визначальне місце в якій займали соціально-просвітницький напрям, що включає в себе праці з основ гігієни; практико-педагогічний напрям, представлений організаційною й викладацькою діяльністю; науково-педагогічний напрям, центрований на розробку проблем шкільної гігієни. Ф.Ф. Ерісман підкреслював важливість масових гігієнічних заходів 3 метою позитивного впливу на здоров'я учнів. Значне місце в дослідженнях вченого займає питання про гігієну розумової праці учнів. В результаті експериментальних досліджень ним були сформульовані загальні гігієнічні засоби боротьби з втомою, визначені норми сну, харчування, розподілу навчальних занять, їх чергування з відпочинком, із заняттями фізичними вправами для школярів відповідно до вікових можливостей. Спеціальну увагу він приділяв організації відпочинку та дозвілля дітей.

У науковій діяльності лікаря-гігієніста Ф. Ерісмана провідне місце займали питання організації освітнього простору, співвідношення зросту учня і розміру шкільних меблів, врахування кількості годин, які дитина проводить у школі і за виконанням домашніх завдань. Він досліджував зір і поставу дітей шкільного віку; обгрунтував проект зразкової класної кімнати й розробив гігієнічні вимоги до класної кімнати; створив спеціальну шкільну парту для зниження ризику короткозорості і збереження прямої постави; виявив закономірності росту дітей в залежності від статі і умов виховання; розробив оціночний показник фізичного розвитку дитини (індекс Ерісмана).

Ключові слова: лікар-гігієніст, шкільна гігієна, Ф. Ф. Ерісман, організація освітнього простору, зразкова класна кімната, шкільна парта.

Постановка проблеми. Педагогічна наука потребує не тільки сучасних теоретичних і прогностичних пошуків, але й творчого критичного аналізу ідей минулого, що дає змогу переосмислити досвід минулого, уникнути серйозних помилок, а також оновити якість освіти на новому рівні. А для цього важливо використовувати будь-яку можливість прочитання педагогічної спадщини класиків вітчизняної педагогіки, бо ця спадщина володіє універсальним духовним потенціалом. Для сучасного вчителя досвід вивчення основ організації освітнього простору безумовно важливий i має аксіологічну 
складову. Досвід педагогів, психологів, педологів, лікарів є цінним щодо ідей про збереження здоров'я дітей, організацію здоров'язберігаючого освітнього простору.

У вітчизняній науці питання збереження здоров'я людини найбільш цілісно було усвідомлене як проблема національної значущості в другій половині XIX ст. У цей період гігієна була виділена як окрема наука, в тому числі i шкільна гігієна. Ї̈̈ основоположниками стали Ф.Ф. Ерісман i О. П. Доброславін. В працях цих вчених профілактичний напрям в охороні здоров'я молоді розглядається як найважливіша умова життєдіяльності. Ф.Ф. Ерісманом були розроблені гігієнічні вимоги до класної кімнати. Він також підкреслював важливість масових гігієнічних заходів 3 метою позитивного впливу на здоров'я учнів. Значне місце в дослідженнях вченого займає питання про гігієну розумової праці учнів. В результаті експериментальних досліджень ним були сформульовані загальні гігієнічні засоби боротьби з втомою, визначені норми сну, харчування, розподілу навчальних занять, їх чергування 3 відпочинком, із заняттями фізичними вправами для школярів відповідно до вікових можливостей. Спеціальну увагу він приділяв організації відпочинку та дозвілля дітей.

Тому метою пропонованої розвідки $\epsilon$ вивчення внеску Федора Федоровича Ерісмана в організацію освітнього простору класної кімнати.

Аналіз останніх досліджень із проблеми. Аналіз наукової літератури 3 питань організації освітнього простору і збереження та зміцненню здоров'я учнів в закладах освіти свідчить про те, що до певної міри досліджували цю проблему О. Бабенкова, Г. Гончарова, А. Макарова, I. Рапопорт та ін. Гігієнічну модель освітнього закладу вивчали В. Андрєєва, М. Антропова, М. Безруких, Д. Колєсов, М. Куїнджі, А. Хрипкова, Д. Шаріпова та ін. Предметно-просторове середовище закладу освіти досліджували Г. Любимова, С. Новосьолова, А. Петровський та ін.

Праці Ф. Ф. Ерісмана у контексті проблеми збереження здоров'я учнів були предметом дослідження О. Верхорубової, В. Кардашенко, О. Лєліної; у контексті проектування шкільних приміщень А. Комлєва (Верхорубова, 2014; Кардашенко, 1985; Лелина, 2006; Комлев, 2007), натомість аналіз внеску Ф. Ерісмана в організацію освітнього простору до сьогодні не проводився.

Виклад основного матеріалу дослідження. Федір Федорович Ерісман (справжнє ім'я Фрідріх Гульдрейх) (1842-1915) - російсько-швейцарський лікар-гігієніст; автор базових принципів гігієни і соціально-гігієнічного напряму медицини, піонер гігієни в Росії. Народився в 1842 р. в Швейцарії; початкову освіту здобув у сільській школі. Після закінчення курсу класичної гімназії в Аарау, Федір Ерісман у 1861 р. вступив на медичний факультет Цюріхського університету. У 1865 р. склав іспит на доктора медицини в Цюріху і став асистентом окуліста, професора Горнера. У 1868 р. Ерісман відвідав Берлін для занять у знаменитого окуліста А. фон Грефе, а потім Відень і Прагу для удосконалення в медичних науках взагалі (Брокгаузь и Ефронь, 1904).

Знайомство з російськими емігрантками, які не мали права вступу до університетів і тому часто виїжджали для навчання за кордон, спричинило виникнення у лікаря інтересу до Росії. Він вивчив російську мову і у 1869 p. переселився до Петербургу, де прийняв православ'я й обрав собі ім'я - Федір Федорович. У Петербурзі склав іспит на доктора медицини у військово- 
медичній академії і спочатку займався приватною практикою 3 лікування хвороб очей, а пізніше досліджував здоров'я учнів в закладах середньої освіти.

Все більше захоплюючись санітарними питаннями, Федір Федорович зовсім припинив практичну діяльність і в 1872 р відправився до Цюріха для здобуття належної підготовки з природничих наук, а потім до Мюнхена, де впродовж двох років займався в фізіологічному інституті професора К. Фойта і в гігієнічній лабораторії знаменитого М. Петтенкофера. У цей період, крім багатьох експериментальних робіт, Ерісманом були написані «Руководство к гигиене» в 3 т., «Профессиональная гигиена или гигиена умственного труда», «Общедоступная гигиена», перекладені на німецьку, голландську, шведську, угорську і фінську мови, ціла низка статей зі шкільної гігієни.

Повернувшись у Петербург, Ф. Ерісман цілком присвятив себе розробці питань загальної і шкільної гігієни. У 1879 р. учений переїхав до Москви, де зайнявся організацією санітарного обстеження фабрик і заводів. 31881 р. Ф. Ерісман почав викладати гігієну в Московському університеті, де у 1882-1896 pp. керував кафедрою гігієни. У лекціях, як і в усіх своїх працях, він підкреслював соціальний характер гігієни. Разом із М. Скліфосовським він брав активну участь у будівництві клінічного містечка медичного факультету університету в Москві. Участь Ф. Ерісмана у проектуванні нових клінік забезпечила будівництво їх за останніми вимогами тогочасної гігієни. В клінічному містечку було збудовано великий гігієнічний корпус, в якому крім навчальних лабораторій Ф. Ерісман влаштував центральну міську санітарну станцію. Після революції 1917 р. цю станцію було перетворено на науководослідний інститут імені Ф. Ерісмана (нині - Федеральний науковий центр гігієни ім. Ф. Ф. Ерісмана).

Ф. Ерісман був постійним доповідачем на Пироговських з'їздах у питаннях соціальної гігієни, боротьби з інфекційними хворобами, не раз він головував на цих з'їдах. Проте прогресивна діяльність лікаря не подобалася правлячим колам царської Росії, і влітку 1896 р., коли під час канікул $Ф$. Ерісман перебував у Швейцарії, його без пояснення причин було звільнено 3 посади професора кафедри гігієни Московського університету. В Росію $Ф$. Ерісман уже не повернувся, але до кінця життя не поривав зв'язку 3 численними своїми учнями, більшість 3 яких очолили кафедри гігієни в університетах або керували губернськими земськими санітарними організаціями. Він вірив, що знищення царизму і капіталізму принесе широким народним масам оздоровлення, звільнить від злиднів і темноти і що Росію чекає велике майбутнє.

Як активний співробітник Енциклопедичного словника Брокгауза i Ефрона, Ф. Ерісман став автором цілої низки статей. Учений продовжував працювати у царині наукової і суспільної гігієни. У 1900 р. він був обраний членом інспекції народних шкіл по Цюріхському округу, у 1901 р - членом цюріхської міської управи і з тих пір завідував санітарною частиною міського громадського управління (Каиров, 1965).

Найбільш відомі роботи Ф. Ерісмана стосуються головним чином досліджень в галузі шкільної та громадської гігієни; учений робив повідомлення з цих питань як на зборах німецьких гігієністів, так і на з’їздах німецьких дослідників природи і лікарів.

Вивчаючи захворювання очей і методи запобігання їм, Федір Ерісман у праці «Влияние школ на происхождение близорукости» (Эрисман, 1870) вказав 
на зростання числа короткозорих дітей і посилення ступеня короткозорості серед учнів в міру наближення закінчення школи. Ретельне обстеження зору учнів 15 петербурзьких гімназій дало ученому змогу розкрити причини короткозорості, розробити заходи щодо попередження короткозорості i гігієнічні вимоги до класних кімнат, які Ф. Ерісман опублікував у вигляді проекту зразкової класної кімнати з раціональним обладнанням. У 1875 р. в Педагогічному музеї військово-навчальних закладів у Петербурзі демонструвався проект Ф. Ерісмана зразкової класної кімнати.

Лікар-гігієніст вважав, що класна кімната - найважливіша частина шкільного приміщення, тому весь план школи має базуватися на тих вимогах, які висуваються до класної кімнати. Так, Федір Федорович обгрунтував форму, абсолютну і відносну величину класної кімнати, зважаючи на особливості шкільного життя (необхідність 3 останніх місць чітко бачити написане на дошці, чути те, що говорить учитель, умови освітлення, шкільна дисципліна i т. п.), необхідний об'єм повітря на кожну дитину, опалення, вентиляція, кількість місць для учнів, розміщення класної дошки і конторки учителя (Эрисман, 1912, с.429).

Основні вимоги, які висував Ф. Ерісман до класного приміщення:

- довжина класного приміщення не більше 9-10 м., так як при більшій довжині вже погано видно букви на дошці;

- висота кімнати повинна бути не менше 4 м., так як при меншій висоті вікна виявляються занадто низькими і денного освітлення не вистачає. При більшій же висоті в кімнаті з'являються акустичні перешкоди;

- відношення площі вікон до площі підлоги дорівнює 1:5;

- вікна повинні розміщатися зліва від учнів, щоб тінь від руки не заважала дітям писати.

Питання освітлення були для Ф. Ерісмана одними 3 найбільш значущих, тому він в пояснювальній записці до своєї «зразкової класної кімнати» пропонував архітектору творчо осмислити необхідність організації широкого світлового фронту. Цікавим і актуальним до сьогодні вважаємо твердження $Ф$. Ерісмана про недоцільність облаштування вікон за спинами учнів. Учений доводив, що «при письмі ці вікна дають привід до виникнення досить різких тіней від голови учнів, завдяки чому корисний на перший погляд вплив вікон, облаштованих за спиною учнів, повністю паралізується» (Эрисман, 1912, c.433).

Учений вважав, що «підлога класної кімнати повинна бути $з$ поганого провідника тепла і не розвивати багато пилу. Найбільш доцільна та ідеальна підлога для класної кімнати - хороший дубовий паркет. Стіни повинні бути прохідні для повітря. Покриття масляною фарбою допускається до певної висоти (2 аршини), інша частина стін і стеля мають бути покриті звичайною клейовою фарбою. Панель може бути пофарбована в темно-сірий колір... Стеля має бути білою, матовою. Всі кути кімнати, а також i карниз округляються задля попередження застою в них повітря i зручності прибирання» (Эрисман, 1895).

Ф. Ерісман працював i над проблемою раціональної конструкції шкільних меблів; розробив шкільну парту власної конструкції, яка отримала згодом назву «парта Ерісмана», визначив основні вимоги до конструкції парти і їі розмірів. Парти були не однакові: лікар розробив чотири ростові варіанти парт для дітей різного віку, при цьому і в класах радив менші парти розміщати 
біля дошки, більші - позаду. На нашу думку, революційною на той час була ідея ученого щодо того, що парти для дівчат і хлопців повинні були мати певні відмінності, оскільки зріст, довжина рук у них різна.

Для того часу це було досить прогресивне технічне рішення, тому що парта Ерісмана була зручною і корисною для здоров’я дітей. У парті Ерісмана стільниця була на 21-22 градуси нахилена до лавки, на якій сидять учні. I хоча робоча поверхня була нахиленою, передбачена була і горизонтальна секція, в якій були заглиблення для чорнильниць і жолоби для ручки чи олівця, аби вони не скочувалися. Внизу для ніг передбачена спеціальна підставкаперекладина, на яку учневі слід було ставити ноги, що теж заважало йому горбитися. Спинка ж лавки була відповідної висоти злегка нахилена від стільниці. Сидячи за партою, дитина мимоволі обирала ту позу і поставу, яка потрібна, щоб хребет не страждав і нормально розвивався. При такому положенні тіла і очі напружуються менше.

Парта мала й недоліки, все ж Ф. Ерісман був лікарем, а не інженером. Одним 3 недоліків було те, що встати з-за неї можна було, тільки відкинувши кришку, створивши оглушливий гуркіт, тому що стіл і лавка були з'єднані. Якщо учень, викликаний до дошки, вставав, то його підручник або зошит зсувалися піднятою кришкою вперед, чіпляли чорнильницю, і весь іiі вміст виливався на спину сидячого попереду учня. Ще одна складність полягала в прибиранні приміщення. Адже парти, з'єднані в один поздовжній ряд i зчеплені між собою виступаючими кінцями своїх полозів - неприступна конструкція, майже недоступна для віника і ганчірки. До недоліків відносили і дорогу вартість парти Ерісмана, так як виробляли їх лише з твердих порід дерева, товщина дошок мала бути від 4 до 6 см.

Наприкінці 80-х pp. XIX ст. студент-народник Петербурзького університету Петро Феоктистович Коротков, засланий в уральське село, де він працював учителем, удосконалив парту Ерісмана i зробив і1і багатофункціональною. Спочатку П. Коротков прикріпив до парт гачки, на які діти могли вішати свої рюкзаки і сумки. Після цього він зробив в партах ящик, де учні могли зберігати свої книги та приладдя для письма. Для того, щоб учням було простіше сідати і вставати з парти, він зробив відкидну кришку. Так одномісна парта Ерісмана перетворилася в двомісну і стала дуже популярною. А Петро Коротков в 1887 р отримав від Урало-Сибірської кустарно-промислової виставки срібну медаль і диплом за винахід парти.

У науковій діяльності лікаря-гігієніста Ф. Ерісмана провідне місце займали питання організації освітнього простору, співвідношення зросту учня і розміру шкільних меблів, врахування кількості годин, які дитина проводить у школі і за виконанням домашніх завдань. Приміром, у праці «Краткий учебник по гигиене» Ф. Ерісман обгрунтував i вимоги до оздоблення стін, до навчального приладдя, до підручників, географічних атласів і т. п. (Эрисман, 1912, с.441).

Учений відстоював ідею організації інституту шкільних лікарів, доводячи, що такий інститут зіграє значну роль у збереженні і покращенні здоров’я учнів. Лікар виступав за введення в школах гарячих сніданків, за розширення шкільного будівництва на науковій основі.

$\Phi$. Ерісман фактично один 3 перших розробив науковий підхід не лише до організації шкіл, але й до організації освітнього простору класу, до охорони здоров'я учнів в умовах школи. 
Висновки і перспективи подальших розвідок. Таким чином, проведене дослідження дає змогу зробити певні узагальнення. У становленні теорії і практики збереження і зміцнення здоров'я дітей, в організації освітнього простору особливе місце займає наукова й педагогічна спадщина Ф. Ф. Ерісмана, яскравого представника вітчизняної науки кінця XIX - початку $\mathrm{XX}$ ст. Важливу роль у формуванні концептуальних ідей Ф. Ф. Ерісмана відіграла багатогранна діяльність вченого, визначальне місце в якій займали соціально-просвітницький напрям, що включає в себе праці з основ гігієни; практико-педагогічний, представлений організаційною й викладацькою діяльністю; науково-педагогічний напрям, центрований на розробку проблем шкільної гігієни. Лікар-гігієніст здійснив дослідження зору і постави у дітей шкільного віку; обгрунтував проект зразкової класної кімнати; учений створив спеціальну шкільну парту для зниження ризику короткозорості і збереження прямої постави; виявив закономірності росту дітей в залежності від статі і умов виховання; розробив оціночний показник фізичного розвитку дитини (індекс Ерісмана).

Перспективу подальших розвідок вбачаємо у аналізі експозиційного комплексу «Зразкова класна кімната» на гігієнічній виставці у Брюселі у 1876 p. та виданої під час виставки доповіді Ф. Ерісмана «Основания устройства классной комнаты и классной мебели», основні тези якої стали основоположними для багатьох європейських країн.

\section{СПИСОК ВИКОРИСТАНИХ ДЖЕРЕЛ:}

Верхорубова, О. (2014). Развитие культуры здоровья будущего учителя в России. Вестник Костромского государственного университета. Серия: Педагогика. Психология. Соииокинетика. №2. Режим доступа: https://cyberleninka.ru/article/n/ravitie-kultury-zdorovya-buduschego-uchitelya-v-rossii

Кардашенко, В. (1985). Физическое развитие. БМЭ. 3 издание. Москва. Т. 26. c. $316-317$.

Лелина, Е. (2006). Русский отдел на первой Международной гигиенической выставке 1876 г. в Брюсселе к 130-летию Международной выставки гигиены и спасения погибающих (1876-2006). Вестник СПбГУ. Серия 2. История. 2006. №4. Режим доступу: https://cyberleninka.ru/article/n/russkiy-otdel-na-pervoymezhdunarodnoy-gigienicheskoy-vystavke-1876-g-v-bryussele-k-130-letiyumezhdunarodnoy-vystavki-gigieny-i-spaseniya-1

Комлев, А. (2007). Типологические аспекты архитектурного проектирования сельских земских школ в Саратовской губернии в конце XIX - начале XX в. Вестник Саратовского государственного технического университета. № 2 (23). cc. $124-128$.

Брокгаузь, Ф. та Ефронь, И. (1904) Эрисман. Энциклопедический словарь: в 86 m. Т. 41(81). Санкт-Петербург. сс. 24-27.

Каиров, И. (1965). Эрисман. Педагогическая энииклопедия [Текст] : [В 4 т.] Москва : Сов. энциклопедия, 1964-1968. Т.4. сс. 797-798.

Эрисман, Ф. (1870). Влияние школ на происхождение близорукости : По наблюдениям над учащимися в учеб. заведениях в С.-Петербурге. Санкт-Петербург : тип. А. М. Котомина, $133 \mathrm{c}$.

Эрисман, Ф. (1912). Краткий учебник по гигиене: 3-е изд., испр. и доп. Москва : А. А. Карцев, $524 \mathrm{c}$.

Эрисман, Ф. (1895). Соображения по вопросу о наилучшем устройстве классной мебели. Москва : тип. Э. Лисснера и Ю. Романа, 15 с. 


\title{
REFERENCES :
}

Verkhorubova. O. (2014). Razvitiye kultury zdorovia budushchego uchitelya v Rossii. [Development of a Future Teacher's Health Culture in Russia]. Vestnik Kostromskogo gosudarstvennogo universiteta. Seriya: Pedagogika. Psikhologiya. Sotsiokinetika. No 2. Rezhim dostupa: https://cyberleninka.ru/article/n/ravitie-kulturyzdorovya-buduschego-uchitelya-v-rossii . [in Russian]

Kardashenko. V. (1985). Fizicheskoye razvitiye. [Physical Development]. BME. 3 izdaniye. Moskva. T. 26. s. 316-317. [in Russian]

Lelina. E. (2006). Russkiy otdel na pervoy Mezhdunarodnoy gigiyenicheskoy vystavke 1876 g. v Bryussele k 130-letiyu Mezhdunarodnoy vystavki gigiyeny i spaseniya pogibayushchikh (1876-2006). [The Russian Department at the First International Hygienic Exhibition 1876 in Brussels to the 130th Aanniversary of the International Exhibition of Hygiene and Rescue of the Perishing (1876-2006)]. Vestnik $S P b G U$. Seriya 2. Istoriya. 2006. No 4. Rezhim dostupu: [in Russian]

Komlev. A. (2007). Tipologicheskiye aspekty arkhitekturnogo proyektirovaniya selskikh zemskikh shkol v Saratovskoy gubernii v kontse XIX - nachale XX v. [Typological Aspects of the Architectural Design of Rural District Schools in the Saratov Province in the Late 19th - Early 20th Centuries]. Vestnik Saratovskogo gosudarstvennogo tekhnicheskogo universiteta. № 2 (23). S 124-128. [in Russian]

Brokgauz. F. \& Efron. I. (1904) Erisman. [Encyclopedic Dictionary: in 86 vol. V. 41 (81)]. Entsiklopedicheskiy slovar: v 86 t. T. 41(81). Sankt-Peterburg. s. 24-27. [in Russian].

Kairov. I. (1965). Erisman.. Pedagogicheskaya entsiklopediya [Pedagogical Encyclopedia [Tekst] : [V 4 t.] Moskva : Sov. entsiklopediya. 1964-1968. T.4. st. 797798. [in Russian].

Erisman. F. (1870). Vliyaniye shkol na proiskhozhdeniye blizorukosti : Po nablyudeniyam nad uchashchimisya $v$ ucheb. zavedeniyakh $v$ S.-Peterburge. [The Iimpact of Schools on the Origin of Myopia: According to the Observations of Students in the educational Institutions in St. Petersburg HA3BA]. Sankt-Peterburg : tip. A. M. Kotomina. 133 s. [in Russian].

Erisman. F. (1912). Kratkiy uchebnik po gigiyene: 3-e izd.. ispr. i dop. [Short tutorial on hygiene]. Moskva : A. A. Kartsev. 524 s. [in Russian].

Erisman. F. (1895). Soobrazheniya po voprosu o nailuchshem ustroystve klassnoy mebeli. [Considerations on the Best Design Classroom Furniture]. Moskva : tip. E. Lissnera i Yu. Romana. 15 s. [in Russian].

\section{THE CONTRIBUTION OF THE PHYSICIAN-HYGIENIST F. ERISMAN TO THE ORGANIXATION OF THE EDUCATIONAL SPACE OF THE CLASSROOM}

Inna Petrenko,

Applicant at the Department of Theory and

Methodology of Education Rivne State University of the Humanities,

Rivne, Ukraine

ORCID: 0000-0003-2320-6100

e-mail:inna.petrenko@rshu.edu.ua

\begin{abstract}
In the article it is analyzed the contribution of a physician-hygienist and teacher, the founder of the national hygienic science and scientific school hygiene in Russia, Swiss-born Fedir Fedorovych Erisman (1842-1915) in the organization of the educational space of the classroom.
\end{abstract}


It is found out that F. Erisman's multifaceted activity played an important role in the formation of his conceptual ideas. It included the following directions: socialeducational one which was the most significant and included works on the basics of hygiene; practical-pedagogical direction, represented by organizational and teaching activity; and scientific-pedagogical direction, centered on the development of problems of school hygiene.

F. Erisman emphasized the importance of mass hygiene measures in order to positively influence the health of students. A significant place in the research of the scientist is devoted to the problem of the hygiene of mental work of students. According to the results of his experimental research, there were formulated by him general hygienic means of dealing with fatigue, determined norms of sleep, nutrition, distribution of studies, their alternation with rest, with physical exercises for schoolchildren in accordance with age possibilities.Special attention was paid to the organization of recreation and leisure for children.

In the scientific activity of the physician-hygienist F. Erisman, the leading place was given to the organization of the educational space, the ratio of the height of a student and the size of school furniture, taking into account the number of hours a child spends in school and does his homework. He investagated the vision and posture of school-age children; he justified the project of an exemplary classroom and developed hygienic requirements for it; created a special school desk to reduce the risk of myopia and maintain a straight posture; revealed patterns of growth of children depending on gender and the conditions of their education; developed an estimate of the physical development of the child (Erisman index).

Key words: hygienist, school hygiene, F. F. Erisman, organization of educational space, exemplary classroom, school desk.

Стаття надійшла до редакиії 29.04.2019 р. 